\title{
Network Proximity Evolution of Open Innovation Diffusion: A Case of Artificial Intelligence for Healthcare
}

\author{
Ben Zhang ${ }^{1}\left(\mathbb{D}\right.$ and Hua Wang ${ }^{2, *} *$ (D) \\ 1 School of Law, Huazhong University of Science and Technology, Wuhan 430074, China; \\ found333@hust.edu.cn \\ 2 School of Management, Huazhong University of Science and Technology, Wuhan 430074, China \\ * Correspondence: amos_huaqin@hust.edu.cn
}

check for

updates

Citation: Zhang, B.; Wang, H. Network Proximity Evolution of Open Innovation Diffusion: A Case of Artificial Intelligence for Healthcare. J. Open Innov. Technol. Mark. Complex. 2021, 7, 222. https://doi.org/ 10.3390/joitmc7040222

Received: 28 July 2021

Accepted: 12 October 2021

Published: 2 November 2021

Publisher's Note: MDPI stays neutral with regard to jurisdictional claims in published maps and institutional affiliations.

Copyright: (c) 2021 by the authors. Licensee MDPI, Basel, Switzerland. This article is an open access article distributed under the terms and conditions of the Creative Commons Attribution (CC BY) license (https:// creativecommons.org/licenses/by/ $4.0 /)$.

\begin{abstract}
Open innovation diffusion is of great significance to industrial transformation and upgrading, forming an open innovation ecosystem based on the patent publication. However, patent applicants contribute much knowledge to the public domain, and the communication channel, which is network proximity, does not receive much attention. This study aimed to explore the key driving factors of open innovation diffusion by constructing a theoretical framework that includes four proximity dimensions in the context of a global industrial chain. By taking artificial intelligence for healthcare as an example, this study applied the quadratic assignment procedure model to conduct an empirical analysis with a sample containing 62 patent applicants. The empirical result verified that the key drivers are from the proximity dimensions and the interactions. Technological proximity plays the leading role in innovation diffusion, while organizational and temporal proximities play secondary roles. In addition, the significant moderating effects suggest that the proximity dimensions interact in innovation activities. Moreover, the proximity framework provides an overview of innovation management and policy implication.
\end{abstract}

Keywords: open innovation diffusion; network proximity; technological proximity; quadratic assignment procedure; artificial intelligence for healthcare; patent system

\section{Introduction}

The innovation flow and diffusion in the open framework of the patent system is of great significance for industrial transformation. Within the system, the public information channel among the patentees lays an essential foundation for learning advanced knowledge. Although the patentees have fierce competitive relationships, it does not prevent obtaining the released innovation achievements from the patent documents. For example, enterprises exclude competitors from receiving competitive advantages through the patent layout by disclosing the technical content as the corresponding price, promoting the development of the whole industrial chain. The innovation diffusion process reflects the fact that organizations commercialize patents in products or services. Especially for emerging technologies, diffusion is one of the manifestations of innovation performance that provides technical benefit and social welfare for the public.

The primary driving forces of open innovation evolution include permission-less innovation, capital mobility, sharing economy, and platform tax [1]. Besides, the dynamics also come from the interaction between local innovation activities and the internationalization of the industrial chain [2]. Exploring the influence mechanism of the innovation diffusion process is necessary for the open innovation system, which helps to understand the dynamics that the technological innovation spreads to the public and avails to identify a more convenient practice path transforming innovation into products or services.

Collaborative innovation, information sharing, or knowledge transfer depend on the knowledge network. Likewise, innovation diffusion in an open innovation system is an internal evolution process which has the property of network topology. Some studies have 
pointed out the proximity characteristics shown in organizational innovation [3,4], but the proximity-influencing mechanism is still unclear for open innovation. Network proximity contributes to the formation of the innovation ecosystem [5], thus supporting the diffusion process of open innovation and promoting economic growth [6]. Moreover, emerging technology has a more superior diffusion performance than traditional technology since the knowledge exchange of technology innovation is more frequent. Following the COVID-19 outbreak, many emerging technologies have been rapidly applied and received widespread public attention. For example, the application of artificial intelligence for healthcare has brought practical assistance to disease diagnosis and drug exploitation, achieving the efficiency and speed that traditional medical technology cannot match.

The above research background indicates the significance of open innovation diffusion in the patent system and the potential support from the complex innovation network. However, the prior research paid scant attention to network proximity, especially at the level of innovative entities. Therefore, the research question proposed in this study is as follows: How should policymakers guide the innovative entities to share innovation more openly? In other words, what are the key driving factors of open innovation diffusion among patent applicants? The theoretical basis comes from the proximity characteristics of innovation activities which can explain collaboration and competition in an emerging technological field. Moreover, the article aims to identify the key drivers of open innovation diffusion, thus understanding the evolution route of open innovation that the study expects to optimize innovation management and policy implementation.

The content of this study is arranged as follows: Section 1 is the introduction which mainly presents the theory source and background of the research problem; Section 2 is the literature review and hypotheses, compiling the existing studies and putting forward the theoretical hypotheses; Section 3 is the methodology, introducing the empirical process design and data source; Section 4 is the analysis results, mainly displaying the empirical analysis for the proximity mechanism; Section 5 is the discussion and conclusions, showing the primary contribution, management implications, and further research plan.

\section{Literature Review and Hypotheses}

\subsection{Open Innovation Theory}

The concept of open innovation has appeared in more and more studies on innovation management in recent years. This type of innovation can form an innovation ecosystem [7], which facilitates innovation cooperation among innovative entities [8]. Moreover, the benefits brought by the innovation lie in the network effect of knowledge flow [9] that promotes the application of new technologies, thus stimulating economic growth. Suh et al. (2019) identified the brokerage patents based on the patent citation network and summarized some essential characteristics of the open innovation model in an emerging industry [10]. Radziwon et al. (2019) discussed the open innovation mechanism in SMEs from the perspective of the innovation ecosystem, pointing out that organizational proximity is one of the core elements for enterprises applying the ecosystem to protocol an open innovation strategy [11].

The concept of proximity is embedded in open innovation and has received much attention in recent research. Boschma (2005), a pioneer of the proximity theory, believes that the multiple dimensions of economic geography presented the impacts on innovation [12] The influence mechanism of proximity is complex, and the concept application has emerged in many research fields. In addition to the technological and organizational proximity, the previous studies discussed cognitive proximity [13], spatial proximity, and temporal proximity [14]. However, Knoben et al. (2006) pointed out the conceptual confusion in proximity theory development through a literature review. The paper summarized the core proximity dimensions and corresponding definitions in the context of interorganizational cooperation [15]. These studies imply that the proximity mechanism has pluralistic factors that influence innovation diffusion. Most existing studies discuss which proximity dimension plays the crucial role in innovation activities. Balland (2012) explored the evolution 
process of the collaborative network from multiple proximity dimensions, and the results show that geography, organization, and institution were the main driving factors [16]. In this study, the open innovation activity is discussed in the context of the patent layout, originating from the technological competence of the patentees. The patent layout is potentially associated with technological proximity, spatial proximity, organizational proximity, and temporal proximity.

As mentioned above, proximity is one of the driving forces for innovation ecosystem formation and open innovation evolution. This feature is manifested in the practice of industrial transformation [17] and enterprise innovation strategy. Patentees learn the outbound knowledge from the patent system and improve the innovation capacity based on the competitive or cooperative relationships constituted by the proximity dimensions. Furthermore, patentees realize competitive advantage through re-innovation. Nestle et al. (2019) found that trust and information asymmetries significantly influence open innovation activities [18]. The asymmetric phenomenon showed that proximity is one of the essential capabilities for innovation entities to achieve network embedding [19]. Multiple entities could exchange information based on specific innovation activity correlations, forming the spiral evolution of innovation [20]. Quinones et al. (2019) studied the university technology transfer and believes that the disharmony between research and commercialization is one of the main factors that form obstacles [21]. Proximity performance determines whether the entity can adapt to the external environment. In addition, proximity reduces the uncertainty of entities in industrial strategic decision-making [22], thus promoting open innovation diffusion.

In an overall view, open innovation diffusion is related to the factors of proximity between the innovative entities. However, few researchers explored the influenced framework of multiple proximity dimensions. Table 1 evaluated the current research trends of open innovation diffusion and four related proximity factors for a deeper understanding.

Table 1. Summary of the related research progress.

\begin{tabular}{|c|c|c|}
\hline Dimensions & Main Research Progress & Limitation \\
\hline Open innovation diffusion & $\begin{array}{l}\text { Innovation ecosystem formation }[7,8,11] \\
\text { Knowledge flow network }[9,20] \\
\text { Open innovation strategy }[10,17,18] \\
\text { Innovation proximity network }[16,19]\end{array}$ & $\begin{array}{l}\text { Ignores the } \\
\text { combination of } \\
\text { multiple proximity } \\
\text { dimensions }\end{array}$ \\
\hline $\begin{array}{l}\text { Technological proximity } \\
\text { Spatial proximity }\end{array}$ & $\begin{array}{l}\text { Interregional innovation networks [23] } \\
\text { Moderating effect of spillover [24] } \\
\text { Weak proximity effect }[25,26] \\
\text { Influence on knowledge creation }[27,28] \\
\text { Promotion effect of proximity }[29,30] \\
\text { Symbiosis relationship [31] } \\
\text { Co-evolutional knowledge network [32] } \\
\text { Technology catchup [33] }\end{array}$ & $\begin{array}{l}\text { Lacks a } \\
\text { comprehensive } \\
\text { explanation for the } \\
\text { interaction of multiple } \\
\text { proximities }\end{array}$ \\
\hline
\end{tabular}

\subsection{Hypotheses Proposed}

\subsubsection{Technological Proximity}

Technological proximity is one of the key topics discussed in the existing studies, especially in the collaborative innovation network. Corte (2018) explored the future research possibility of open innovation through bibliometrics, such as the relationship between innovation and co-competition and the impact on competitive advantage [34]. Technological proximity lays the foundation of collaboration for organizations with similar characteristics, causing competition for living space and development environment. Letaifa et al. (2013) believes that exorbitant technological proximity would hinder innovation and entrepreneurial performance, indicating how obstacles operate specifically from the dimension of geographical proximity [35]. These previous studies show that the influence of proximity on innovation is positive in some situations, and the result can become negative after the 
change of conditions. Sun et al. (2017) argued that technological proximity plays a positive role in evolving interregional technology-trading networks [23]. In the field of patents, technological proximity is also emergent within the application. Similar organizations or individuals collaborate in the R \& D activity and jointly apply for patents, which leads to more innovation diffusion [24]. The studies mentioned above indicate that although patent rights restrict the competitors from acquiring innovative knowledge, the knowledge released by patentees stimulates further innovation. Based on this, the following hypothesis is proposed:

Hypothesis 1 (H1). Technological proximity has a positive effect on open innovation diffusion.

\subsubsection{Spatial Proximity}

Spatial proximity is one of the critical dimensions of proximity, which is also known as geographic proximity. Entities that are close to each other can exchange knowledge more conveniently, thus facilitating innovation formation. Marrocu et al. (2013) studied regional technology innovation and believes geographic proximity has a weaker effect on innovation than technological proximity [25]. The spatially proximate regions tend to cooperate in $\mathrm{R} \& \mathrm{D}$ activities, but the situation is reversed at the international level [36]. Besides, spatial proximity presents relations to other proximity dimensions, which means moderating the other dimensions. Capaldo et al. (2014) found that the impacts of geographic proximity and organizational proximity on alliance innovation performance are interdependent [27]. Guan et al. (2016) argued that geographic proximity has no moderating effect on the relationship between technological proximity and recombinative innovation [26]. For multinational enterprises, the global patent layout strategy usually goes along with the international trade activity since patents have the territorial scope of legal protection. Protection of the exported products or services further strengthens the local application of technology innovation. Furthermore, enterprises can access advanced knowledge from the patent documents, thus reducing $\mathrm{R} \& \mathrm{D}$ costs and risks [28]. Based on this, we have the following hypothesis:

Hypothesis 2 (H2). Spatial proximity has a positive effect on open innovation diffusion.

\subsubsection{Organizational Proximity}

An interorganizational knowledge network is essential for innovative entities to participate in open innovation [37]. Open innovation diffusion depends on the network structure of the knowledge flow, and organizational proximity is one of the driving factors affecting the network structure. Cao et al. (2019) found that proximity factors promote the evolution of innovation networks and enhance innovation capability through empirical analysis. The results argued that organizational proximity plays the most critical role [29]. By discussing the influence of power relations on proximity in collaborative innovation, Hansen et al. (2017) believes that a specific power system could promote the learning of subordinates from the superior organization [30]. Besides, the network topology of proximity is a popular way whereby organizational proximity affects innovation performance. Velenturf et al. (2016) studied the industrial ecology based on proximity and identified the specific path to realize the evolution of industrial symbiosis [31]. Ferras-Hernandez et al. (2018) studied the relationship between enterprise innovation performance and proximity concentrating on innovation activities, identifying the main factors that drive the industrial cluster's innovation transformation, including attraction, information, interaction, expectation, and competition [38]. Therefore, the following hypothesis is proposed:

Hypothesis 3 (H3). Organizational proximity has a positive effect on open innovation diffusion. 


\subsubsection{Temporal Proximity}

Temporal proximity of the patent layout indicates that patentees implement the patent strategy in a short time interval, which promotes the emergence of emerging technologies and forms a prominent competitive relationship. However, this proximity dimension was often ignored in the existing literature [39]. Only a few studies discussed the dynamic evolution attribute of knowledge diffusion, which points out the limitations of the static feature of the existing proximity theory. Balland et al. (2015) argued that static proximity is challenging to enhance understanding knowledge network evolution, discussing the coevolution state of a knowledge network and proximity from a dynamic perspective [32] Lazzeretti et al. (2016) also studied the proximity problem of innovation networks dynamically, and the conclusion indicated proximity influences the industry evolution through the network structure [40]. As a unique one embedded in various dimensions, temporal proximity is inseparable from other dimensions and promotes the technology catchup process with the incumbents [33]. Menzel (2015) believes that dynamic proximity could impact the proximity dimensions of cognition, network, and space [41]. The concentrated distribution of patents over a period leads to the patent thicket, which poses a significant obstacle for patent licensing. Therefore, this study proposes the following hypothesis:

Hypothesis 4 (H4). Temporal proximity has a negative effect on open innovation diffusion.

\section{Methodology}

\subsection{Empirical Research Method}

Since the purpose was to explore the influencing mechanism of proximity factors on the innovation diffusion process, applying the data on relationships between the patent applicants was necessary to perform the empirical analysis. The traditional empirical analysis methods such as ordinary least squares and logistic regression usually fit the sectional or panel data. Besides, these methods need to satisfy the strict assumptions, which do not apply to the research problem of this paper. The quadratic assignment procedure (QAP) is a suitable choice, which is an empirical research method for the relational comparison of the matrix data, generally including correlation analysis and regression analysis. Therefore, this study chooses the QAP methods to verify the proposed research hypotheses. Moreover, Table 2 sets the empirical variables for the QAP model.

Table 2. Empirical variable setting.

\begin{tabular}{|c|c|c|}
\hline Variables & Name & Connotation \\
\hline $\mathrm{Y}$ & $\begin{array}{l}\text { Open innovation } \\
\text { diffusion }\end{array}$ & $\begin{array}{l}\text { Patent citation relationship between the patent } \\
\text { applicants in a specific technology field }\end{array}$ \\
\hline $\mathrm{X}_{1}$ & $\begin{array}{c}\text { Technological } \\
\text { proximity }\end{array}$ & $\begin{array}{l}\text { Technical branch cooccurrence relationship between } \\
\text { the patent applicants: this study classified the } \\
\text { branches according to the international patent } \\
\text { classification (IPC) at the subgroup level, and the } \\
\text { corresponding values are from the IPC statistics }\end{array}$ \\
\hline $\mathrm{X}_{2}$ & Spatial proximity & $\begin{array}{l}\text { Patent jurisdiction cooccurrence relationship between } \\
\text { the patent applicants }\end{array}$ \\
\hline$X_{3}$ & $\begin{array}{l}\text { Organizational } \\
\text { proximity }\end{array}$ & $\begin{array}{l}\text { Judgment matrix of organization similarity between } \\
\text { the patent applicants: the proximity in the matrix is } \\
\text { assigned the value of one if similar and zero if not } \\
\text { similar; the organization attributes include university } \\
\text { (or institution) and enterprise. }\end{array}$ \\
\hline $\mathrm{X}_{4}$ & Temporal proximity & $\begin{array}{l}\text { Timespan cooccurrence relationship between the } \\
\text { patent applicants }\end{array}$ \\
\hline
\end{tabular}

\subsection{Data Source}

The research data are from the patent information for artificial intelligence for healthcare. For further empirical analysis, the patent data were cleaned and transformed into 
relationship data. The study formulated the technological field-related patent retrieval strategy, and the selected search keywords were from the official report "WIPO Technology Trends 2019-Artificial Intelligence" (https:/ / www.wipo.int/edocs/pubdocs/en/wipo pub_1055.pdf, accessed on 22 October 2020). We performed the retrieval process in the Incopat database, and the retrieval timespan was 2000-2019. Besides, the patent search also adopted the international patent classification (IPC) to avoid the noise data. Therefore, the final patent retrieval code was as follows:

$\left(\left(\mathrm{TIABC}=\left(\left(\right.\right.\right.\right.$ "artificial intelligen" ${ }^{*}$ OR "natural language process" ${ }^{*}$ OR "information extrac $^{*}$ " OR "machine translat*" OR "natural language generat" ${ }^{*}$ " OR "semantics" OR "machine learning" OR "image* recogn" ${ }^{*}$ OR "computer vision" OR "scene understand" OR "speech recogn*" OR "cloud comput*" OR "pattern recogn" OR "video recogn*" OR "supervised learn*" OR "unsupervised learn*" OR "reinforced learn" OR "multi-task learn*" OR "classification tree*" OR "regression tree*" OR "support vector machine $e^{* \prime}$ OR "artificial neural network*" OR "deep learn" OR "logical learn" OR "relational learn*" OR "probabilistic graphical model" ${ }^{*}$ OR "rule learn" based learni*" OR "latent representation" OR "bio-inspired approach*" OR "biometrics" OR "recommend* system" OR "logic program*" OR "fuzzy logic" OR "probabilistic reason" ${ }^{*}$ OR "ontology engineer" OR "search system" $\left.)\right)$ AND TIABC $=\left(\left(\right.\right.$ medic ${ }^{*}$ OR drug OR diagnos* OR treatment OR health)) AND (IPC-LOW $=($ A61 OR G03 OR G16H OR G16B OR G16C OR G21F OR G03B15/14 OR B82Y5 OR G03B42/02))) AND (AD = [20000101 TO 20191231]).

Through searching in the Incopat database, 6703 patents were obtained. Then, we reprocessed the patent data to extract the relationships between the patent applicants. The entities with more than nine patents regarded as the core players in artificial intelligence for healthcare were filtered from the searched patents. Moreover, 62 patent applicants and the corresponding patent information constitute the research sample. Finally, as mentioned in Table 2, the research sample was transformed into the matrix data for the five variables. The descriptive statistics of each variable are shown in Table 3.

Table 3. Descriptive statistics.

\begin{tabular}{cccccc}
\hline & $\mathbf{Y}$ & $\mathbf{X}_{\mathbf{1}}$ & $\mathbf{X}_{\mathbf{2}}$ & $\mathbf{X}_{\mathbf{3}}$ & $\mathbf{X}_{\mathbf{4}}$ \\
\hline Mean & 2.34 & 18.22 & 4.19 & 0.52 & 9.02 \\
Standard & 10.24 & 27.73 & 6.76 & 0.5 & 8.9 \\
deviation & 8838 & 68,908 & 15,848 & 1958 & 34,112 \\
Sum & 104.94 & 768.78 & 45.75 & 0.25 & 79.16 \\
Variance & 0 & 0 & 0 & 0 & 0 \\
Minimum & 212 & 484 & 49 & 1 & 193 \\
Maximum & 3782 & 3782 & 3782 & 3782 & 3782 \\
No. of obs. & & & & & \\
\hline
\end{tabular}

\section{Empirical Analysis Results}

\subsection{QAP Correlation Analysis}

The result of QAP correlation analysis is shown in Table 4, indicating that open innovation diffusion is positively correlated with technological proximity, spatial proximity, organizational proximity, and temporal proximity. There are also significant positive correlations between the proximity dimensions. For technological proximity, the other three proximity dimensions all have positive correlations. As for spatial proximity, organizational proximity and temporal proximity have positive correlations. However, there was no significant correlation between organizational proximity and temporal proximity. The above correlation result shows that the four proximity dimensions all have a specific impact on the diffusion of open innovation. However, there were also potential interactions between the proximity dimensions since almost every proximity dimension is related to another. 
Table 4. QAP correlation analysis result.

\begin{tabular}{|c|c|c|c|c|c|}
\hline & $Y$ & $X_{1}$ & $X_{2}$ & $X_{3}$ & $X_{4}$ \\
\hline$Y$ & - & & & & \\
\hline$X_{1}$ & $\begin{array}{c}0.845^{* * *} \\
(0.000)\end{array}$ & - & & & \\
\hline$X_{2}$ & $\begin{array}{c}0.385^{* * *} \\
(0.000)\end{array}$ & $\begin{array}{c}0.403 * * * \\
(0.000)\end{array}$ & - & & \\
\hline$X_{3}$ & $\begin{array}{l}0.135^{* *} \\
(0.002)\end{array}$ & $\begin{array}{l}0.127^{*} \\
(0.015)\end{array}$ & $\begin{array}{l}0.144^{* *} \\
(0.003)\end{array}$ & - & \\
\hline$X_{4}$ & $\begin{array}{c}0.664^{* * *} \\
(0.000)\end{array}$ & $\begin{array}{c}0.822^{* * * *} \\
(0.000)\end{array}$ & $\begin{array}{c}0.289 * * * \\
(0.000)\end{array}$ & $\begin{array}{c}0.070 \\
(0.095)\end{array}$ & - \\
\hline
\end{tabular}

\subsection{QAP Regression Result}

Table 5 shows the result of the QAP regression analysis. Models 1-6 examined the influence of every two proximity dimensions on innovation diffusion, respectively, while model 7 tested the comprehensive influence of all the proximity dimensions. Table 5 presents the normalized regression coefficients, and the values in brackets are the corresponding $p$-values. Therefore, the regression coefficients could observe the strength of the effects and whether other effects existed. The regression result of model 7 indicated that the proximity dimensions had different effects on innovation diffusion. Technological proximity $(\beta=0.896, p=0.000)$, spatial proximity $(\beta=0.047, p=0.008)$, and organizational proximity $(\beta=0.014, p=0.160$ ) had significant positive impacts on innovation diffusion. Besides, temporal proximity ( $\beta=-0.087, p=0.006$ ) had a significant negative effect on innovation diffusion. The regression coefficients of these proximity dimensions reflected that the influence of technological proximity was the highest, followed by the other three proximity dimensions. Thus, it can be concluded that technological proximity plays the leading role in innovation diffusion.

Table 5. QAP regression result of proximity dimensions.

\begin{tabular}{cccccccc}
\hline Variable & Model 1 & Model 2 & Model 3 & Model 4 & Model 5 & Model 6 & Model 7 \\
\hline$X_{1}$ & $0.824^{* * *}$ & $0.843^{* * *}$ & $0.923^{* * *}$ & & & & $0.896^{* * *}$ \\
& $(0.000)$ & $(0.000)$ & $(0.000)$ & & & & $(0.000)$ \\
$X_{2}$ & $0.053^{* * *}$ & & & $0.377^{* * *}$ & $0.210^{* * *}$ & & $0.047^{* *}$ \\
& $(0.004)$ & & & $(0.000)$ & $(0.000)$ & & $(0.008)$ \\
$X_{3}$ & & 0.022 & & 0.049 & & $0.070^{* * *}$ & $0.014^{*}$ \\
& & $(0.074)$ & & $(0.065)$ & & $(0.000)$ & $(0.160)$ \\
$X_{4}$ & & & $-0.094^{*}$ & & $0.603 * * *$ & $0.660^{* * *}$ & $-0.087^{* *}$ \\
Intercept & -3.543 & -3.567 & -2.892 & -0.579 & -5.262 & -5.261 & -3.238 \\
$\boldsymbol{R}^{2}$ & 0.716 & 0.714 & 0.717 & 0.150 & 0.481 & 0.446 & 0.719 \\
\hline Note: ${ }^{* * *}, p<0.001 ; * *, p<0.01 ; *, p<0.05$. & & & & &
\end{tabular}

Table 6 shows the QAP regression result for further verifying the interaction between every two proximity dimensions. Models $8-13$, respectively, tested the interactive influence of every two proximity dimensions on innovation diffusion. Model 14 tested the comprehensive influence on innovation diffusion, including the proximity dimensions and their interactions. The regression result of model 14 showed that technological proximity ( $\beta=0.893, p=0.000)$ and organizational proximity $(\beta=0.041, p=0.005)$ still had significant positive impacts on innovation diffusion. In contrast, temporal proximity ( $\beta=-0.083$, $p=0.010$ ) still had a significant negative effect on innovation diffusion. It should be noted that the impact of spatial proximity was insignificant in model 14. Through comparing Tables 5 and 6 , the empirical analysis results finally verified hypothesis 1 , hypothesis 3 , and hypothesis 4 since the corresponding three dimensions presented significant influences. 
However, the insignificant effect of spatial proximity in Table 6 indicates that hypothesis 2 cannot be fully supported.

Table 6. QAP regression result of proximity interactions.

\begin{tabular}{|c|c|c|c|c|c|c|c|}
\hline Variable & Model 8 & Model 9 & $\begin{array}{c}\text { Model } \\
10\end{array}$ & $\begin{array}{c}\text { Model } \\
11\end{array}$ & $\begin{array}{c}\text { Model } \\
12\end{array}$ & $\begin{array}{c}\text { Model } \\
13\end{array}$ & $\begin{array}{c}\text { Model } \\
14\end{array}$ \\
\hline$X_{1}$ & $\begin{array}{c}0.758^{* * *} \\
(0.000)\end{array}$ & $\begin{array}{c}0.859 * * * \\
(0.000)\end{array}$ & $\begin{array}{c}0.929 * * * \\
(0.000)\end{array}$ & & & & $\begin{array}{c}0.893^{* * *} \\
(0.000)\end{array}$ \\
\hline$X_{2}$ & $\begin{array}{l}0.032 * \\
(0.038)\end{array}$ & & & $\begin{array}{c}0.308^{* * *} \\
(0.000)\end{array}$ & $\begin{array}{c}0.135^{* * *} \\
(0.000)\end{array}$ & & $\begin{array}{c}0.001 \\
(0.431)\end{array}$ \\
\hline$X_{3}$ & & $\begin{array}{l}0.029 * \\
(0.024)\end{array}$ & & $\begin{array}{l}-0.016 \\
(0.259)\end{array}$ & & $\begin{array}{l}0.060 * * \\
(0.003)\end{array}$ & $\begin{array}{l}0.041 \text { ** } \\
(0.005)\end{array}$ \\
\hline$X_{4}$ & & & $\begin{array}{c}-0.090 \\
* * * \\
(0.001)\end{array}$ & & $\begin{array}{c}0.384^{* * *} \\
(0.000)\end{array}$ & $\begin{array}{c}0.636^{* * *} \\
(0.000)\end{array}$ & $\begin{array}{c}-0.083 \text { ** } \\
(0.010)\end{array}$ \\
\hline$X_{1} \times X_{2}$ & $\begin{array}{c}0.088^{* * *} \\
(0.001)\end{array}$ & & & & & & $\begin{array}{c}0.186^{* * *} \\
(0.000)\end{array}$ \\
\hline$X_{1} \times X_{3}$ & & $\begin{array}{c}-0.035^{* *} \\
(0.010)\end{array}$ & & & & & $\begin{array}{c}-0.092 \text { * } \\
(0.028)\end{array}$ \\
\hline$X_{1} \times X_{4}$ & & & $\begin{array}{l}-0.011 \\
(0.416)\end{array}$ & & & & $\begin{array}{c}-0.190 \text { ** } \\
(0.003)\end{array}$ \\
\hline$X_{2} \times X_{3}$ & & & & $\begin{array}{c}0.191 * * * \\
(0.000)\end{array}$ & & & $\begin{array}{c}-0.056 \text { * } \\
(0.014)\end{array}$ \\
\hline$X_{2} \times X_{4}$ & & & & & $\begin{array}{c}0.298^{* * *} \\
(0.000)\end{array}$ & & $\begin{array}{l}0.068 \text { * } \\
(0.045)\end{array}$ \\
\hline$X_{3} \times X_{4}$ & & & & & & $\begin{array}{l}0.054 \text { * } \\
(0.016)\end{array}$ & $\begin{array}{l}0.094 \text { * } \\
(0.012)\end{array}$ \\
\hline $\begin{array}{c}\text { Intercept } \\
R^{2}\end{array}$ & $\begin{array}{c}-3.482 \\
0.718\end{array}$ & $\begin{array}{c}-3.400 \\
0.715\end{array}$ & $\begin{array}{c}-2.909 \\
0.717\end{array}$ & $\begin{array}{c}-1.700 \\
0.176\end{array}$ & $\begin{array}{c}-4.933 \\
0.507\end{array}$ & $\begin{array}{c}-5.750 \\
0.448\end{array}$ & $\begin{array}{c}-3.519 \\
0.726\end{array}$ \\
\hline
\end{tabular}

The regression result of the interactions also shows that there were moderating effects between proximity dimensions. Except that the interaction between technological and temporal proximity was not significant, other interactions all had significant effects. Technological proximity had negative moderating effects on both organizational proximity and temporal proximity. Table 6 shows that the influence of organizational proximity ( $\beta=-0.035, p=0.010$ ) on innovation diffusion would decrease by 0.035 . The influence of temporal proximity $(\beta=-0.190, p=0.003$ ) on innovation diffusion would decrease by 0.19 if the technological proximity were to increase by 1 in the meantime. Spatial proximity had significant positive moderating impacts on technological proximity, organizational proximity, and temporal proximity. The influence of technological proximity $(\beta=0.088$, $p=0.001$ ) on innovation diffusion would increase by 0.088 , while the influence of organizational proximity $(\beta=0.191, p=0.000$ ) on innovation diffusion would increase by 0.191 . The influence of temporal proximity ( $\beta=0.298, p=0.000$ ) would increase by 0.298 if the spatial proximity were to increase by 1 simultaneously. In addition, organizational proximity had a positive moderating effect on temporal proximity, indicating that the influence of temporal proximity $(\beta=0.054, p=0.016$ ) on innovation diffusion would increase by 0.054 if organizational proximity were to increase by 1 at the same time.

\section{Discussion and Conclusions}

This study explored the influence mechanism of open innovation diffusion based on multiple proximity dimensions. The proposed theoretical framework tried to fill the research gap of open innovation diffusion since the existing research [3-6] provided few explanations for the influence mechanism of network proximity on innovation diffusion. Moreover, the empirical analysis focused on the emerging technology field of artificial intelligence for healthcare in the patent system, which applied the QAP regression with the patent data. The results show that technological proximity was the most dominant 
dimension that positively impacted open innovation diffusion. The closer the technological proximity between innovative entities, the more frequent the innovation sharing based on the patent information present, improving the output quality and innovation efficiency in innovation activities.

Besides, three other proximity dimensions presented different effects. Organizational proximity positively affected open innovation diffusion, while temporal proximity had a negative effect. The result interprets why transferring technology from universities to enterprises is difficult, which supplements the theory based on the prior literature [21,22]. Enterprises tend to learn advanced technology from other enterprises, especially the competitors, and the situation is the same for universities. It is interesting to note that spatial proximity had no significant effect on the innovation diffusion process under the interaction of proximity dimensions. Although the prior research $[27,28]$ emphasized the promotion of spatial proximity, the result of this study decreases the importance of this dimension and implies that regions will converge with each other for more efficient innovation sharing.

The main theoretical contribution lies in the fact that the study constructed an analysis framework describing open innovation diffusion based on multiple network proximities, while many existing studies $[13,19,28,30]$ focused on independent dimensions. The four proximity dimensions play significant independent and interactive roles at the same time. The proximity mechanism provides an overview of innovation management, indicating the network topology characteristic of open innovation diffusion. Moreover, the mechanism can also explain how open innovation diffusion evolves to the innovation ecosystem in the patent system. Patent applicants utilize the existing technology to form further innovation, which is a spontaneous and circulatory process. Thus, industrial decision-makers can outline a value chain by identifying cooperative opportunities or competitive challenges from the knowledge flow network.

This study summarized the following management and policy implications. First, industrial decision-makers need to strengthen the level of technological proximity between innovation entities. Technological proximity plays a leading role in innovation diffusion, according to the empirical result. Therefore, this measure is a conventional approach to promote innovation diffusion in industrial clusters. Second, innovation policy needs to coordinate the organizational structure and the patent layout strategy within the industrial cluster. Since organizational proximity and temporal proximity play secondary roles, these proximity characteristics provide an auxiliary means of amplifying the propulsion effect brought by technological proximity. Third, governments can plan to promote the unification of the patent systems in various regions. The various patent systems are the main obstacles to innovation diffusion. Therefore, international cooperation on patent protection is possible to be positive, thus exerting the moderating effect of spatial proximity.

However, this study also has some inevitable limitations. On the one hand, the empirical research sample only selected a part of patent applicants, which may not reflect the comprehensive situation in artificial intelligence for healthcare. On the other hand, there were significant differences in patent quantity between the applicants, which might have affected the regression results. Therefore, further research ought to optimize the research design. The research sample should be expanded, and group regression analysis ought to be carried out to verify whether the difference between the applicant groups affects the innovation diffusion process.

Author Contributions: Conceptualization, B.Z. and H.W.; methodology, B.Z.; validation, B.Z.; formal analysis, B.Z. and H.W.; investigation, B.Z. and H.W.; resources, B.Z.; data curation, H.W.; writingoriginal draft preparation, B.Z. and H.W.; writing-review and editing, B.Z.; supervision, B.Z.; project administration, H.W.; funding acquisition, B.Z. All authors have read and agreed to the published version of the manuscript.

Funding: This research was funded by the Project of Humanities and Social Sciences (20YJC630201) of the Ministry of Education of China (MOE). 
Institutional Review Board Statement: Not applicable.

Informed Consent Statement: Not applicable.

Data Availability Statement: Restrictions apply to the availability of these data. Data was obtained from Incopat and are available at https: / /www.incopat.com/ with the permission of Incopat. accessed on 22 October 2020.

Acknowledgments: The authors acknowledge the support of Society of Open Innovation: Technology, Market, and Complexity (SOI) and Riga Technical University 2021 Conference.

Conflicts of Interest: The authors declare no conflict of interest.

\section{References}

1. Yun, J.J.; Park, K.; Hahm, S.D.; Kim, D. Basic Income with High Open Innovation Dynamics: The Way to the Entrepreneurial State. J. Open Innov. Technol. Mark. Complex. 2019, 5, 41. [CrossRef]

2. Bettiol, M.; Chiarvesio, M.; Di Maria, E.; Gottardello, D. Local or global? Does internationalization drive innovation in clusters? Eur. Plan Stud. 2019, 27, 1995-2014. [CrossRef]

3. Franco, M.; Esteves, L. Inter-clustering as a network of knowledge and learning: Multiple case studies. J. Innov. Knowl. 2020, 5, 39-49. [CrossRef]

4. Ooms, W.; Piepenbrink, R. Open Innovation for Wicked Problems: Using Proximity to Overcome Barriers. Calif. Manag. Rev. 2021, 63, 62-100. [CrossRef]

5. Komninos, N.; Kakderi, C.; Collado, A.; Papadaki, I.; Panori, A. Digital Transformation of City Ecosystems: Platforms Shaping Engagement and Externalities across Vertical Markets. J. Urban Technol. 2021, 28, 93-114. [CrossRef]

6. Brink, T. Organising of dynamic proximities enables robustness, innovation and growth: The longitudinal case of small and medium-sized enterprises (SMEs) in food producing firm networks. Ind. Mark. Manag. 2018, 75, 66-79. [CrossRef]

7. Sekliuckiene, J.; Sedziniauskiene, R.; Viburys, V. Adoption of Open Innovation in the Internationalization of Knowledge Intensive Firms. Eng. Econ. 2016, 27, 607-617. [CrossRef]

8. Leckel, A.; Veilleux, S.; Dana, L.P. Local Open Innovation: A means for public policy to increase collaboration for innovation in SMEs. Technol. Soc. 2020, 153, 119891. [CrossRef]

9. Öberg, C.; Alexander, A.T. The openness of open innovation in ecosystems-Integrating innovation and management literature on knowledge linkages. J. Innov. Knowl. 2019, 4, 211-218. [CrossRef]

10. Suh, Y.; Jeon, J. Monitoring patterns of open innovation using the patent-based brokerage analysis. Technol. Soc. 2019, 146, 595-605. [CrossRef]

11. Radziwon, A.; Bogers, M. Open innovation in SMEs: Exploring inter-organizational relationships in an ecosystem. Technol. Soc. 2019, 146, 573-587. [CrossRef]

12. Boschma, R. Proximity and Innovation: A Critical Assessment. Reg. Stud. 2005, 39, 61-74. [CrossRef]

13. O'Connor, M.; Doran, J.; McCarthy, N. Cognitive proximity and innovation performance: Are collaborators equal? Eur. J. Innov. Manag. 2020, 24, 637-654. [CrossRef]

14. Liu, Y.; Shao, X.; Tang, M.; Lan, H. Spatio-temporal evolution of green innovation network and its multidimensional proximity analysis: Empirical evidence from China. J. Clean. Prod. 2021, 283, 124649. [CrossRef]

15. Knoben, J.; Oerlemans, L.A.G. Proximity and inter-organizational collaboration: A literature review. Int. J. Manag. Rev. 2006, 8, 71-89. [CrossRef]

16. Balland, P. Proximity and the Evolution of Collaboration Networks: Evidence from Research and Development Projects within the Global Navigation Satellite System (GNSS) Industry. Reg. Stud. 2012, 46, 741-756. [CrossRef]

17. Lee, I.; Kim, E. Factors Affecting the Outbound Open Innovation Strategies in Pharmaceutical Industry: Focus on Out-Licensing Deal. J. Open Innov. Technol. Mark. Complex. 2019, 5, 73. [CrossRef]

18. Nestle, V.; Täube, F.A.; Heidenreich, S.; Bogers, M. Establishing open innovation culture in cluster initiatives: The role of trust and information asymmetry. Technol. Soc. 2019, 146, 563-572. [CrossRef]

19. Shi, X.; Zheng, Z.; Zhang, Q.; Liang, H. External knowledge search and firms' incremental innovation capability: The joint moderating effect of technological proximity and network embeddedness. Manag. Decis. 2020, 58, 2049-2072. [CrossRef]

20. Leydesdorff, L. Synergy in Knowledge-Based Innovation Systems at National and Regional Levels: The Triple-Helix Model and the Fourth Industrial Revolution. J. Open Innov. Technol. Mark. Complex. 2018, 4, 16. [CrossRef]

21. Quiñones, R.; Caladcad, J.A.; Quiñones, H.; Caballes, S.A.; Abellana, D.P.; Jabilles, E.M.; Himang, C.; Ocampo, L. Open Innovation with Fuzzy Cognitive Mapping for Modeling the Barriers of University Technology Transfer: A Philippine Scenario. J. Open Innov. Technol. Mark. Complex. 2019, 5, 94. [CrossRef]

22. Ye, L.; Zeng, G.; Cao, X. Open innovation and innovative performance of universities: Evidence from China. Growth Chang. 2020, 51, 1142-1157. [CrossRef]

23. Sun, Y.; Grimes, S. The actors and relations in evolving networks: The determinants of inter-regional technology transaction in China. Technol. Soc. 2017, 125, 125-136. [CrossRef] 
24. Wang, C.; Zhang, G. Examining the moderating effect of technology spillovers embedded in the intra- and inter-regional collaborative innovation networks of China. Scientometrics 2019, 119, 561-593. [CrossRef]

25. Marrocu, E.; Paci, R.; Usai, S. Proximity, networking and knowledge production in Europe: What lessons for innovation policy? Technol. Soc. 2013, 80, 1484-1498. [CrossRef]

26. Guan, J.C.; Yan, Y. Technological proximity and recombinative innovation in the alternative energy field. Res. Policy 2016, 45, 1460-1473. [CrossRef]

27. Capaldo, A.; Petruzzelli, A.M. Partner Geographic and Organizational Proximity and the Innovative Performance of KnowledgeCreating Alliances. Eur. Manag. Rev. 2014, 11, 63-84. [CrossRef]

28. Kapetaniou, C.; Lee, S.H. Geographical proximity and open innovation of SMEs in Cyprus. Small. Bus. Econ. 2019, 52, 261-276. [CrossRef]

29. Cao, X.; Zeng, G.; Ye, L. The structure and proximity mechanism of formal innovation networks: Evidence from Shanghai high-tech ITISAs. Growth Chang. 2019, 50, 569-586. [CrossRef]

30. Hansen, T.; Mattes, J. Proximity and power in collaborative innovation projects. Reg. Stud. 2018, 52, 35-46. [CrossRef]

31. Velenturf, A.P.M.; Jensen, P.D. Promoting Industrial Symbiosis: Using the Concept of Proximity to Explore Social Network Development. J. Ind. Ecol. 2016, 20, 700-709. [CrossRef]

32. Balland, P.; Boschma, R.; Frenken, K. Proximity and Innovation: From Statics to Dynamics. Reg. Stud. 2015, 49, 907-920. [CrossRef]

33. Rosiello, A.; Maleki, A. A dynamic multi-sector analysis of technological catch-up: The impact of technology cycle times, knowledge base complexity and variety. Res. Policy 2021, 50, 104194. [CrossRef]

34. Della Corte, V. Innovation through Coopetition: Future Directions and New Challenges. J. Open Innov. Technol. Mark. Complex. 2018, 4, 47. [CrossRef]

35. Letaifa, S.B.; Rabeau, Y. Too close to collaborate? How geographic proximity could impede entrepreneurship and innovation. J. Bus. Res. 2013, 66, 2071-2078. [CrossRef]

36. Fitjar, R.D.; Rodríguez-Pose, A. The geographical dimension of innovation collaboration: Networking and innovation in Norway. Urban. Stud. 2014, 51, 2572-2595. [CrossRef]

37. Rasiah, R. Building Networks to Harness Innovation Synergies: Towards an Open Systems Approach to Sustainable Development. J. Open Innov. Technol. Mark. Complex. 2019, 5, 70. [CrossRef]

38. Ferras Hernandez, X.; Nylund, P.A. Clusters as Innovation Engines: The Accelerating Strengths of Proximity. Eur. Manag. Rev. 2018, 16, 37-53. [CrossRef]

39. Tanner, A.N. Changing locus of innovation: A micro-process approach on the dynamics of proximity. Eur. Plan. Stud. 2018, 26, 2304-2322. [CrossRef]

40. Lazzeretti, L.; Capone, F. How proximity matters in innovation networks dynamics along the cluster evolution. A study of the high technology applied to cultural goods. J. Bus. Res. 2016, 69, 5855-5865. [CrossRef]

41. Menzel, M. Interrelating Dynamic Proximities by Bridging, Reducing and Producing Distances. Reg. Stud. 2015, 49, 1892-1907. [CrossRef] 